\title{
DETERMINAN PERILAKU LANSIA DALAM PEMANFAATAN POSYANDU LANSIA DI WILAYAH KERJA PUSKESMAS PAYO SELINCAH KOTA JAMBI TAHUN 2020
}

\author{
Determinants of Elderly Behavior in Utilization of Elderly Posyandu in the Work Area \\ of Payo Selincah Primary Health Care in Jambi City in 2020
}

\author{
Raden Muhammad Ifwazan Darusman ${ }^{1}$, La Ode Reskiaddin ${ }^{1}$, Guspianto ${ }^{1}$ \\ ${ }^{1}$ Program Studi Ilmu Kesehatan Masyarakat, FKIK Universitas Jambi, Indonesia
}

\begin{abstract}
Abstrak
Posyandu lansia merupakan sebuah program puskesmas yang ditujukan untuk memberikan pelayanan kesehatan bagi lansia dengan melibatkan peran serta masyarakat dan berbagai sektor. Laporan Dinas Kesehatan Kota Jambi tahun 2018 menunjukkan cakupan pelayanan kesehatan lansia di Puskesmas Payo Selincah Kota Jambi hanya sebesar 85,5\% yaitu masih dibawah target SPM (100\%). Data kehadiran lansia perbulan tahun 2019 di posyandu lansia Cempaka Harum dan Anggrek wilayah kerja Puskesmas Payo Selincah sangat rendah yaitu hanya 8 orang $(2,1 \%)$ dan 7 orang $(0,41 \%)$. Tujuan penelitian ini adalah untuk mengetahui determinan perilaku lansia dalam pemanfaatan posyandu lansia di wilayah kerja Puskesmas Payo Selincah Kota Jambi. Penelitian ini adalah penelitian kuantitatif dengan desain cross sectional, menggunakan teknik pengambilan sampel proportionate random sampling dengan jumlah sampel sebanyak 92 orang lansia. Penelitian dilakukan pada bulan juni hingga juli tahun 2020. Intrumen penelitian menggunakan kuesioner. Hasil penelitian diketahui $73,5 \%$ lansia tidak memanfaatkan posyandu. Hasil uji statistik chi-square diketahui p- value pengetahuan sebesar 0,408 (> 0,05), sikap sebesar 0,718 (>0,05), jarak sebesar 0,000 $(<0,05)$, dukungan keluarga sebesar 1,000 (> $0,05)$ dan peran kader sebesar $0,000(<0,05)$. Terdapat hubungan yang signifikan antara faktor jarak dan peran kader dalam pemanfaatan posyandu lansia di wilayah kerja Puskesmas Payo Selincah Kota Jambi.

Kata Kunci : Lansia, Posyandu lansia, Jarak, Peran Kader
\end{abstract}

\begin{abstract}
Elderly posyandu was a Primary Health Care program for the elderly which was involved by the participation of the community and various sectors. In 2018, Jambi City Health Office reported that the coverage of elderly health services in The Payo Selincah Primary Health Care in Jambi City was only $85.5 \%$ which was still below the SPM target (100\%). Data on average elderly attendance per month in 2019 in senior posyandu Cempaka Harum and Anggrek in the working area of Puskesmas Payo Selincah was still very low, that only 8 people $(2.1 \%)$ and 7 people $(0.41 \%)$. This study aimed to detemine the determinants of elderly behavior in the utilization of the elderly posyandu in Puskesmas Payo Selincah Jambi City. This study was quantitative with cross sectional design,with the sampling techniques used proportionate random sampling with the number of samples were 92 elderly people. The research was conducted from June to July 2020. The research instruments used questionnaires. The results of this research showed that $73.5 \%$ of the elderly did not use the posyandu for the elderly. The results of the chi-square test showed that the p-value of knowledge was $0.408(>0.05)$, attitude $0.718(>0.05)$, distance $0.000(<0.05)$, family support $1,000(>0.05)$ and the role of cadres $0,000(<0.05)$. So it can be concluded that there were significant relationship between the distance factor and the role of cadres with the utilization of elderly posyandu in the work area of Puskesmas Payo Selincah, Jambi City.

Keywords : Elderly, Elderly Posyandu, Distance, Role of Cadres.
\end{abstract}

Korespondensi : Raden Muhammad Ifwazan Darusman

Email : $\underline{\text { ifwazandarusman@gmail.com }}$ 


\section{PENDAHULUAN}

Lansia (Lanjut Usia) diartikan sebagai seseorang yang sudah berusia 60 tahun keatas (1). Populasi lansia di dunia saat ini telah melebihi angka 7\% dari populasi penduduk yang berarti bahwa populasi dunia telah memasuki era penduduk menua (ageing population). Pada tahun 2017, populasi lansia di dunia telah mencapai 962 juta yaitu meningkat dua kali lipat daripada tahun 1980 yakni sebesar 382 juta jiwa di dunia. Diprediksikan jumlah ini akan tetap mengalami peningkatan di tahun 2050 hingga mencapai 2,1 miliar lansia di seluruh dunia (2). Kawasan atau wilayah yang memiliki populasi lansia terbesar di dunia yaitu berada di Asia Timur dan Tenggara dengan jumlah lansia sebesar 260 juta jiwa (3).

Negara Indonesia merupakan salah satu negara di Asia Tenggara yang turut mengalami penambahan jumlah penduduk lansia sekitar dua kali lipat dalam rentan waktu hampir lima dekade (1971-2019). Total lansia di di Indonesia tahun 2019 berjumlah 25,64 juta jiwa $(9,60 \%)$ meningkat dibandingkan tahun 2018 yaitu sebanyak 24,49 juta jiwa (9,27\%) (4). Diperkirakan di tahun 2020 peningkatan total penduduk lansia di Indonesia akan terus berlangsung hingga mencapai angka 28,8 juta jiwa (11,34\%). (5) Provinsi Jambi adalah salah satu wilayah di Indonesia yang mengalami penambahan penduduk lansia dengan jumlah 3,52 juta jiwa (2017) meningkat menjadi 3,57 juta jiwa (2018) (6). Kota Jambi merupakan wilayah kabupaten/kota dengan jumlah penduduk lansia terbanyak di Provinsi Jambi dengan total 41,8 ribu jiwa yang terdiri dari 20,8 ribu laki-laki dan 21 ribu perempuan (7).
Meningkatnya jumlah lansia di dunia dan di Indonesia dipengaruhi oleh kemajuan pada sektor kesehatan yang mengakibatkan terjadinya penambahan usia harapan hidup penduduk (UHH) sehingga berakibat menjadi meningkatnya jumlah penduduk lansia. (4) Semakin bertambahnya jumlah lansia dimasa mendatang dapat menimbulkan pengaruh yang positif jika lansia memiliki keadaan yang sehat, aktif dan juga produktif. Sebaliknya, banyaknya jumlah lansia dapat menimbulkan dampak negatif karena membebani bila lansia mengalami permasalahan seperti menurunnya kesehatan yang berdampak menjadi meningkatnya biaya layanan kesehatan, menurunnya pendapatan/penghasilan, meningkatnya jumlah disabilitas, tidak ada dukungan sosial dan kondisi lingkungan yang tidak simpatik kepada lansia (8).

Beberapa permasalahan kesehatan yang banyak dialami oleh lanisa berdasarkan data hasil Riskesdas (2018) diantaranya yaitu hipertensi $(63,5 \%)$, masalah gigi $(53,6 \%)$, penyakit sendi (18\%), masalah mulut (17\%), diabetes melitus $(5,7 \%)$ penyakit jantung $(4,5 \%)$, stroke $(4,4 \%)$, gagal ginjal $(0,8 \%)$ dan kanker $(0,4 \%)$ (9).

Salah satu upaya yang dijalankan pemerintah untuk meningkatkan derajat kesehatan lansia adalah dengan mencanangkan program kegiatan posyandu lansia. Posyandu lansia atau Pos pelayanan terpadu lanjut usia merupakan wadah pelayanan kesehatan yang berasal dari masyarakat guna memberikan pelayanan kepada masyarakat lansia, dibentuk dan dilaksanakan oleh masyarakat bersama-sama dengan lembaga swadaya masyarakat, serta lintas sektor baik pemerintah ataupun non 
pemerintah, swasta, organisasi sosial dan lainnya yang memfokuskan pelayanan kesehatan dengan upaya promotif dan preventif (10).

Terlaksananya kegiatan posyandu lansia dengan baik akan memudahkan lansia untuk memperoleh layanan kesehatan sehingga derajat kesehatan lansia dapat terjaga dengan baik dan maksimal. Sebaliknya, apabila lansia tidak menggunakan layanan kesehatan pada posyandu lansia akan mengakibatkan keadaan kesehatannya tidak bisa diketahui dan teramati dengan baik. Kondisi ini berisiko bagi lansia apabila tanpa disadari lansia mengalami permasalahan kesehatan. Apabila hanya dibiarkan dapat memperburuk kesehatan lansia dan bahkan dapat mengancam keselamatan dirinya. Oleh karena itu, mengikuti kegiatan posyandu lansia menjadi sesuatu hal yang penting bagi lansia untuk menjaga dan meningkatkan derajat kesehatannya (11).

Berdasarkan data Dinas Kesehatan Kota jambi (2018), diketahui bahwa Puskesmas Payo Selincah memiliki cakupan pelayanan kesehatan lansia yang paling rendah diantara 20 puskesmas yang ada di Kota Jambi yaitu sebesar 85,5\% (2018) atau masih dibawah target SPM (100\%) (12). Berdasarkan data kehadiran lansia tahun 2019 di posyandu lansia yang terdapat di wilayah kerja Puskesmas Payo Selincah diketahui bahwa rata-rata jumlah lansia yang hadir setiap bulannya masih sangat rendah yaitu sebanyak 8 orang $(2,1 \%)$ dari 378 lansia yang terdapat di posyandu Cempaka Harum kelurahan Payo Selincah dan sebanyak 7 orang $(0,41 \%)$ dari 1705 lansia yang terdapat posyandu Anggrek Eka Jaya.
Dari penjelasan yang telah diuraikan diatas maka peneliti terdorong untuk melaksanakan penelitian yang berjudul "Determinan Perilaku Lansia dalam Pemanfaatan Posyandu Lansia di Wilayah Kerja Puskesmas Payo Selincah Kota Jambi”.

\section{METODE}

Penelitian ini merupakan penelitian kuantitatif dengan desain potong lintang (cross sectional). Variabel independen dalam penelitian ini yaitu pengetahuan, sikap, jarak, dukungan keluarga dan peran kader. Sedangkan variabel dependen penelitian yaitu pemanfaatan posyandu lansia. Penelitian dilakukan pada bulan juni-juli 2020. Populasi penelitian adalah lansia (> 60 tahun) yang tinggal di wilayah kerja Puskesmas Payo Selincah Kota Jambi. Pengambilan sampel dilakukan dengan proportionate random sampling dengan jumlah responden sebanyak 92 orang lansia. Pengumpulan data menggunakan kuesioner. Analisis data dalam penelitian ini dilakukan dengan analisis Univariat dan Bivariat. Analisis Bivariat dilakukan menggunakan uji analisis Chi-Square yang dioperasikan menggunakan program aplikasi pengolah data SPSS. 


\section{HASIL}

\section{A. ANALISIS UNIVARIAT}

\section{Tabel 1. Distribusi Pemanfaatan Posyandu Lansia dan Karakteristik Responden}

\begin{tabular}{|c|c|c|c|}
\hline Variabel & & f & $\%$ \\
\hline \multicolumn{4}{|c|}{ Pemanfaatan Posyandu Lansia } \\
\hline & Kurang Baik & 84 & 91,3 \\
\hline & Baik & 8 & 8,7 \\
\hline & Total & 92 & 100 \\
\hline \multicolumn{4}{|l|}{ Usia } \\
\hline & 60-74 tahun & 69 & 75 \\
\hline & 75-90 tahun & 23 & 25 \\
\hline & Total & 92 & 100 \\
\hline \multicolumn{4}{|c|}{ Jenis Kelamin } \\
\hline & Laki-laki & 42 & 45,7 \\
\hline & Perempuan & 50 & 54,3 \\
\hline & Total & 92 & 100 \\
\hline \multicolumn{4}{|c|}{ Pendidikan } \\
\hline & Tidak Tamat SD & 37 & 40,2 \\
\hline & Tamat SD & 28 & 30,4 \\
\hline & Tamat SMP & 12 & 13 \\
\hline & Tamat SLTA & 15 & 16,3 \\
\hline & Total & 92 & 100 \\
\hline \multicolumn{4}{|l|}{ Pekerjaan } \\
\hline & Ibu Rumah Tangga (IRT) & 37 & 40,2 \\
\hline & Pensiunan & 6 & 6,5 \\
\hline & Petani & 12 & 13 \\
\hline & Pedagang & 15 & 16,3 \\
\hline & Buruh & 11 & 12 \\
\hline & Wirausaha & 1 & 1,1 \\
\hline & Guru & 1 & 1,1 \\
\hline & Tidak Bekerja & 9 & 9,8 \\
\hline & Total & 92 & 100 \\
\hline
\end{tabular}

Sumber : Data Primer,2020.

Berdasarkan tabel 1 diketahui bahwa sebanyak 84 orang $(91,3 \%)$ responden tidak memanfaatkan posyandu lansia. Responden berdasarkan karakteristik yang paling banyak ditemukan adalah usia 60-74 tahun sebanyak
69 orang $(75 \%)$, jenis kelamin perempuan sebanyak 50 orang $(54,7 \%)$, pendidikan Tidak Tamat SD sebanyak 37 orang (40,2\%), dan pekerjaan Ibu Rumah Tangga (IRT) sebanyak 37 orang (40,2\%). 


\section{B. ANALISIS BIVARIAT}

Tabel 2. Distribusi Pemanfaatan Posyandu Lansia dan Karakteristik Responden

\begin{tabular}{|c|c|c|c|c|c|c|c|c|}
\hline \multirow{3}{*}{$\begin{array}{c}\text { Variabel } \\
\text { Independen }\end{array}$} & \multicolumn{6}{|c|}{ Pemanfaatan Posyandu Lansia } & \multirow[t]{3}{*}{ P-value } & \multirow{3}{*}{$\begin{array}{c}\text { PR }(95 \% \\
\text { CI) }\end{array}$} \\
\hline & \multicolumn{2}{|c|}{$\begin{array}{c}\text { Tidak } \\
\text { Memanfaatkan }\end{array}$} & \multicolumn{2}{|c|}{ Memanfaatkan } & \multicolumn{2}{|c|}{ Jumlah } & & \\
\hline & $\mathrm{n}$ & $\%$ & $\mathrm{n}$ & $\%$ & $\mathbf{n}$ & $\%$ & & \\
\hline \multicolumn{9}{|l|}{ Pengetahuan } \\
\hline Kurang Baik & 64 & 92,8 & 5 & 7,2 & 69 & 100 & 0,408 & $1,07(0,89-$ \\
\hline Baik & 20 & 87 & 3 & 13 & 23 & 100 & & $1,27)$ \\
\hline \multicolumn{9}{|l|}{ Sikap } \\
\hline $\begin{array}{l}\text { Kurang Baik } \\
\text { Baik }\end{array}$ & 35 & 89,7 & 4 & 10,3 & 39 & 100 & 0,718 & $\begin{array}{c}0,97(0,85- \\
1,11)\end{array}$ \\
\hline \multicolumn{9}{|l|}{ Jarak } \\
\hline Jauh & 15 & 93,8 & 1 & 6,3 & 16 & 100 & 0,000 & $1,83(1,11-$ \\
\hline Sedang & 62 & 98,4 & 1 & 1,6 & 63 & 100 & & 3,03 \\
\hline Dekat & 7 & 53,8 & 6 & 6 & 13 & 100 & & \\
\hline \multicolumn{9}{|c|}{ Dukungan Keluarga } \\
\hline Kurang Baik & 58 & 90,6 & 6 & 9,4 & 64 & 100 & 1,000 & $0,98(0,86-$ \\
\hline Baik & 26 & 92,9 & 2 & 7,1 & 28 & 100 & & $1,11)$ \\
\hline \multicolumn{9}{|l|}{ Peran Kader } \\
\hline Kurang Baik & 82 & 97,6 & 2 & 2,4 & 84 & 100 & 0,000 & $3,91(1,17-$ \\
\hline Baik & 2 & 25,0 & 6 & 75 & 8 & 100 & & $12,97)$ \\
\hline
\end{tabular}

Sumber : Data Primer, 2020.

Berdasarkan tabel 2 diatas diketahui bahwa proporsi lansia yang tidak memanfaatkan posyandu lansia lebih besar pada responden dengan pengetahuan kurang baik $(92,8 \%)$ dibandingkan dengan pengetahuan baik (87\%). Hasil analisis bivariat didapatkan pengetahuan hanya meningkatkan $1,07 \quad$ kali terhadap pemanfaatan posyandu lansia di wilayah kerja Puskesmas Payo Selincah Kota Jambi dan tidak terbukti secara signifikan berpengaruh.

Proporsi lansia yang tidak memanfaatkan posyandu lansia lebih besar pada responden dengan sikap baik $(92,5 \%)$ dibandingkan dengan sikap kurang baik $(89,7 \%)$. Hasil analisis bivariat didapatkan sikap hanya meningkatkan 0,97 kali terhadap pemanfaatan posyandu lansia di wilayah kerja Puskesmas Payo Selincah Kota Jambi dan tidak terbukti secara signifikan berpengaruh.

Proporsi lansia yang tidak memanfaatkan posyandu lansia lebih besar pada responden dengan jarak sedang $(98,4 \%)$ dibandingkan dengan jarak jauh $(92,8 \%)$ dan jarak dekat $(53,8 \%)$. Hasil analisis bivariat didapatkan jarak meningkatkan 1,83 kali terhadap pemanfaatan posyandu lansia di wilayah kerja Puskesmas Payo Selincah Kota Jambi dan terbukti secara signifikan berpengaruh.

Proporsi lansia yang tidak memanfaatkan posyandu lansia lebih besar 
pada responden dengan dukungan keluarga kurang baik $(90,6 \%)$ dibandingkan dengan dukungan keluarga baik (92,9\%). Dari hasil bivariat didapatkan pengetahuan hanya meningkatkan 0,98 kali terhadap pemanfaatan posyandu lansia di wilayah kerja Puskesmas Payo Selincah Kota Jambi dan tidak terbukti secara signifikan berpengaruh.

Proporsi lansia yang tidak memanfaatkan posyandu lansia lebih besar pada responden dengan peran kader kurang baik $(97,6 \%)$ dibandingkan dengan pengetahuan baik (25\%). Dari hasil bivariat didapatkan peran kader meningkatkan 3,91 kali terhadap pemanfaatan posyandu lansia di wilayah kerja Puskesmas Payo Selincah Kota Jambi dan terbukti secara signifikan berpengaruh.

\section{PEMBAHASAN}

\section{Gambaran Pemanfaatan Posyandu Lansia}

Posyandu lansia ialah sebuah wadah pelayanan kesehatan yang berasal dari masyarakat, dibentuk dan dilaksanakan oleh masyarakat dengan lembaga swadaya masyarakat (LSM), lintas sektor pemerintah atau non pemerintah, swasta, organisasi sosial dan lain-lain guna memberikan layanan kepada penduduk lansia dengan berfokus pada langkah promotif dan preventif (10). Keberadaan posyandu lansia memiliki manfaat yang baik bagi lansia, diantaranya guna meningkatkan status kesehatan, kemandirian, memperlambat aging proces, mendeteksi dini permasalahan kesehatan, menambah usia harapan hidup (13).

Berdasarkan hasil penelitian diketahui dari 92 reponden penelitian bahwa sebanyak 84 orang $(73,5 \%)$ tidak memanfaatkan posyandu lansia dan sebanyak 8 orang $(26,5 \%)$ yang memanfaatkan posyandu lansia. Dengan demikian, disimpulkan bahwa lebih banyak jumlah lansia yang tidak memanfaatkan posyandu lansia dibandingkan yang memanfaatkan.

Pemanfaatan posyandu lansia yang telah dilakukan merupakan cerminan dari sikap lansia dalam merespon suatu objek yang berkaitan dengan pelayanan kesehatan atau biasa disebut dengan perilaku kesehatan. Pemanfaatan ini dilakukan guna memeriksakan, menjaga dan meningkatkan derajat kesehatan lansia (14).

Dari hasil penelitian dan observasi peneliti di lapangan diketahui bahwa mayoritas lansia tidak memanfaatkan posyandu lansia dikarenakan lokasi posyandu yang jauh dari rumah dan informasi yang masih belum sampai kepada masyarakat atau lansia sehingga mengakibatkan masih banyak yang tidak mengetahuinya.

\section{Hubungan Pengetahuan dengan Pemanfaatan Posyandu Lansia}

Berdasarkan hasil penelitian diketahui bahwa lansia dengan pengetahuan kurang baik berisiko lebih besar 1,07 kali tidak melakukan pemanfaatan posyandu lansia dibandingkan dengan pengetahuan baik. Hasil uji statistik chi-square diketahui bahwa pengetahuan tidak mempunyai hubungan dengan pemanfaatan posyandu lansia di wilayah kerja Puskesmas Payo Selincah Kota Jambi dengan $p$-value $=0,408$ $(>0,05)$.

Sejalan dengan hasil penelitian Yuniati Faiza (2014) yaitu pengetahuan tidak berhubungan dengan pemanfaatan posyandu 
lansia ( $p=0,074)$. Penyebabnya ialah dalam pemanfaatan posyandu lansia dipengaruhi oleh banyak faktor diantaranya sikap, informasi yang diperoleh, pengalaman dan sosial ekonomi (15).

Pengetahuan ialah hasil tau dari sistem penginderaan dengan melihat, mendengar, mencium, merasa dan meraba (melalui mata, telinga, hidung, lidah dan tangan) pada suatu objek tertentu (16). Pengetahuan merupakan salah satu faktor yang mempengaruhi motivasi seseorang untuk berperilaku. Tetapi, pengetahuan belum tentu selalu memotivasi seseorang untuk berperilaku baik, seperti halnya pengetahuan tentang posyandu lansia belum tentu membuat lansia termotivasi untuk hadir ke posyandu (17).

Dalam penelitan ini, mayoritas lansia mempunyai pengetahuan kurang baik dan tidak memanfaatkan posyandu lansia disebabkan karena tidak mengetahui infomasi tentang posyandu. Menurut Notoatmodjo (2007) pengetahuan merupakan salah satu faktor predisposisi (melekat) yang berpengaruh terhadap perilaku seseorang, pengetahuan dipengaruhi oleh berbagai faktor seperti tingkat pendidikan, minat, pengalaman, umur dan informasi (18). Faktor pendidikan diperkirakan juga mempengaruhi lansia dalam memanfaatkan posyandu dikarenakan sebagian besar lansia memiliki tingkat pendidikan tidak tamat SD (40,2\%),

Lansia yang mempunyai pengetahuan baik tetapi tidak memanfaatkan posyandu lansia dikarenakan adanya kesibukan atau pekerjaan yang dilakukan lansia seperti melakukan pekerjaan rumah tangga dan lainnya. Hal ini sesuai dengan temuan di lapangan yaitu kebanyakan pekerjaan lansia ialah sebagai ibu rumah tangga (IRT) berjumlah 37 orang (40,2\%). Sesuai dengan penelitian yang dilakukan Khoiriah (2018) membuktikan bahwa pekerjaan berhubungan dengan pemanfaatan posyandu lansia (19).

Tidak sejalan dengan hasil penelitian Aryatiningsih (2014) yaitu pengetahuan berhubungan terhadap pemanfaatan posyandu lansia dengan $\mathrm{p}$-value $=0,026$; CI 95; POR 1,726 (1,092-2,729) (17).

Dari hasil penelitian ini bisa disimpulkan bahwa lansia yang mempunyai pengetahuan kurang baik maupun pengetahuan baik cenderung tidak memanfaatkan posyandu lansia, sehingga pengetahuan tidak berpengaruh terhadap pemanfaatan posyandu lansia.

\section{Hubungan Sikap dengan Pemanfaatan Posyandu Lansia}

Berdasarkan hasil penelitian diketahui bahwa lansia dengan sikap baik berisiko lebih besar 0,97 kali tidak melakukan pemanfaatan posyandu lansia dibandingkan dengan sikap kurang baik. Hasil uji statistik chi-square diketahui bahwa tidak ada hubungan antara sikap dengan pemanfaatan posyandu lansia di wilayah kerja Puskesmas Payo Selincah Kota Jambi dengan $\mathrm{p}$-value $=0,718(>0,05)$.

Sejalan dengan penelitian Sari, Asrinawaty, Dhewi (2020) menunjukkan bahwa sikap lansia tidak memiliki hubungan dengan pemanfaatan posyandu lansia di wilayah kerja Puskesmas Banjar Baru (20).

Sebaliknya tidak sejalan dengan penelitian Purnama. S, Sudirman, Yusuf. H (2017) yang menunjukkan bahwa sikap berhubungan terhadap pemanfaatan posyandu lansia $(\mathrm{p}=0,001)(21)$. 
Sikap ialah sebuah reaksi atau respon seseorang yang masih tertutup terhadap stimulus atau suatu objek. Kesiapan seseorang untuk bereaksi kepada objek pada lingkungan tertentu sebagai suatu penghayatan terhadap objek (18). Dengan sikap positif, seseorang cenderung melakukan tindakan seperti mendekati, menyenangi, dan mengharapkan objek tertentu. Sedangkan pada sikap negatif, kecenderungan tindakan seperti tidak mendekati, menghindar, memebenci dan tidak sama dengan menyukai objek tertentu (22).

Pada situasi tertentu sikap yang positif belum tentu selalu membuat lansia akan aktif memanfaatkan posyandu lansia. Sejalan dengan hasil penelitian Rusmin, Bujawati dan Habiba (2017) yakni lansia dengan dengan sikap positif namun kurang aktif memanfaatkan posyandu disebabkan oleh rasa malas dan keadaan tubuh yang kurang mendukung karena mengalami pegal linu, kram, osteoporosis, rematik dan lumpuh akibatnya jadi tidak memanfaatkan posyandu lansia (22).

Dari hasil penelitian dan observasi di lapangan diketahui bahwa lansia yang mempunyai sikap baik namun tidak melakukan pemanfaatan posyandu lansia disebabkan karena kurang meratanya informasi yang diterima lansia sehingga mereka tidak mengetahui adanya kegiatan posyandu lansia di wilayah tempat tinggal mereka. Sedangkan lansia yang mempunyai sikap kurang baik tetapi tidak memanfaatkan posyandu lansia disebabkan karena faktor pengetahuan lansia yang kurang tentang manfaat posyandu lansia. Sikap positif tidak terlepas dari pengetahuan, apabila pengetahuan seseorang tersebut baik, maka dapat terbentuk sikap yang positif dari lansia untuk mengunjungi posyandu lansia. Sikap yang utuh dipengaruhi oleh peran penting dari pengetahuan, pikiran, keyakinan dan emosi.

\section{Hubungan Jarak dengan Pemanfaatan Posyandu Lansia}

Berdasarkan hasil penelitian diketahui bahwa lansia dengan jarak sedang berisiko lebih besar 1,83 kali tidak melakukan pemanfaatan posyandu lansia dibandingkan dengan jarak jauh dan dekat. Hasil uji statistik chi-square diketahui bahwa jarak berhubungan dengan pemanfaatan posyandu lansia di wilayah kerja Puskesmas Payo Selincah Kota Jambi dengan p-value = $0,000(<0,05)$.

Penelitian Rahayu menunjukkan hasil yang sejalan yakni jarak berhubungan dengan pemanfaatan posyandu lansia (23). Didukung pula oleh Sayati (2018) yang menunjukkan jarak berhubungan signifikan dengan pemanfaatan posyandu lansia di wilayah kerja Puskesmas 7 Ulu Palembang (24).

Hasil penelitian ini tidak sejalan dengan hasil penelitian Kompiang (2015) yaitu jarak tidak berhubungan terhadap pemanfaatan posyandu lansia ( $\mathrm{p}=0,092$; OR $=1,841 ; 95 \% \mathrm{CI}=0,902-3,758)$, yang berarti lansia dengan jarak posyandu dekat berpeluang 1,841 kali untuk lebih baik dalam memanfaatkan posyandu daripada lansia yang mempunyai jarak jauh (25).

Kemudahan dalam menjangkau pelayanan kesehatan memiliki hubungan dengan perilaku lansia dalam memanfaatkan posyandu lansia. Hal ini sejalan dengan teori 
Lawrence Green dalam Notoatmodjo (2005) yang menjelaskan bahwa lingkungan fisik atau letak geografis mempengaruhi perilaku seseorang dalam pelayanan kesehatan. Dekatnya lokasi posyandu bisa memudahkan lansia untuk datang tanpa perlu merasakan kelelahan ataupun kecelakaan fisik disebabkan menurunnya kekuatan fisik (14).

Dalam penelitian ini, mayoritas lansia mempunyai jarak tempuh yang cukup jauh dan merasa sulit untuk menjangkau lokasi posyandu lansia. Menurut Ismawati, Pebriyanti dan Proverawati (2010) mudahnya mengakses posyandu berkaitan terhadap keamanan atau keselamatan diri lansia. Apabila keamanan ataupun kemudahan untuk mengakses posyandu dirasakan oleh lansia dengan tidak mengalami rasa lelah atau permasalahan yang parah lainnya, maka dengan demikian dapat mendorong minat dan semangat lansia berperan serta dalam posyandu lansia. Selain itu, lansia yang memiliki jarak jauh dan dekat namun tidak memanfaaatkan posyandu lansia dipengaruhi oleh beberapa faktor seperti lupa jadwal posyandu, pekerjaan, sikap, permasalahan kesehatan yang dialami lansia dan tidak adanya yang mengantarkan (26).

\section{Hubungan Dukungan Keluarga dengan Pemanfaatan Posyandu Lansia}

Berdasarkan hasil penelitian diketahui bahwa lansia dengan dukungan keluarga baik berisiko lebih besar 0,98 kali tidak melakukan pemanfaatan posyandu lansia dibandingkan dengan dukungan keluarga kurang baik. Hasil uji statistik chisquare diketahui bahwa dukungan keluarga tidak mempunyai hubungan dengan pemanfaatan posyandu lansia di wilayah kerja Puskesmas Payo Selincah Kota Jambi dengan $\mathrm{p}$-value $=1,00(>0,05)$.

Sejalan dengan hasil penelitian Yuniati (2014) bahwa dukungan keluarga tidak berhubungan terhadap pemanfaatan posyandu lansia. Penyebabnya ialah karena begitu besar pengaruh sifat bantuan keluarga yang dipengaruhi oleh faktor lain diantaranya seperti perekonomian, susunan keluarga, derajat hubungan, kebutuhan lainnya dan tenaga yang tersedia (15).

Hasil penelitian ini tidak sejalan dengan hasil penelitian Sari, Asrinawaty dan Dhewi (2020) yaitu tidak ada hubungan dukungan keluarga dengan pemanfaatan posyandu lansia $(\mathrm{p}=0,236>0,05)(20)$.

Menurut Friedman (1998) keluarga adalah unit terkecil dilingkup masyarakat yang berperan sebagai klien penerima asuhan serta berperan untuk menentukan pola asuh yang dibutuhkan bagi anggota keluarganya yang mengalami masalah kesehatan. Diantara tugas dari keluarga adalah untuk merawat anggota keluarga dan memanfaatkan ketersediaan fasilitas kesehatan (27).

Dukungan anggota keluarga sangatlah diperlukan bagi lansia demi keberlangsungan kegiatan posyandu lansia yakni dengan memotivasi dan memberikan dorongan bagi lansia untuk selalu memanfaatkan posyandu. Pentingnya dukungan keluarga kepada lansia dikarenakan keluarga merupakan support sytem utama bagi lansia dalam menjaga dan memelihara kesehatannya. Menurut Padila (2013) keluarga berperan untuk menjaga atau merawat lansia, mempertahankan dan meningkatkan status mental, mengantisipasi perubahan status sosial-ekonomi dan 
memberikan motivasi (dukungan), serta memfasilitasi kebutuhan spritual bagi lansia (27). Selain itu, keluarga juga dapat menjadi motivator bagi lansia dengan selalu bersedia mendampingi dan mengantarkan lansia ke posyandu serta menjadi pengingat bagi lansia apabila lupa jadwal dan berupaya membantu menyelesaikan masalah yang dihadapi lansia (26).

Dari hasil penelitian dan pengamatan di lapangan diketahui bahwa mayoritas lansia mempunyai dukungan keluarga yang baik terhadap kegiatan posyandu, tetapi dalam pemanfaatannya masih kurang baik. Hal ini disebabkan karena belum meratanya informasi dan sosialisasi tentang kegiatan posyandu lansia yang mengakibatkan masih banyak masyarakat atau keluarga lansia yang tidak tau apa itu posyandu lansia dan tidak mengetahui keberadaannya sehingga mereka tidak mengikutsertakan lansia anggota keluarganya pada kegiatan posyandu.

\section{Hubungan Peran Kader dengan Pemanfaatan Posyandu Lansia}

Berdasarkan hasil penelitian diketahui bahwa lansia dengan peran kader kurang baik berisiko lebih besar 3,90 kali tidak melakukan pemanfaatan posyandu lansia dibandingkan dengan peran kader baik. Hasil uji statistik chi-square diketahui bahwa peran kader berhubungan dengan pemanfaatan posyandu lansia di Wilayah Kerja Puskesmas Payo Selincah Kota Jambi tahun 2020 dengan p-value $=0,000(<0,05)$.

Kader adalah orang yang memiliki peran penting dalam penyelenggaraan posyandu lansia, kader memiliki tanggung jawab pada masyarakat khususnya lansia, kader bertugas dan berperan menjadi pelaku dalam suatu sistem kesehatan (29). Saat menjalankan tugasnya kader perlu memiliki kepribadian atau sikap dan perilaku yang baik sehingga bisa dinilai baik pula oleh peserta atau pengunjung posyandu lansia (30).

Pada kegiatan posyandu lansia kader mempunyai peran penting untuk menjadikan aktif atau tidaknya kegiatan posyandu karena kader selaku pemberi motivator atau promotor kesehatan yang bertugas menyokong petugas kesehatan dalam upaya menambah kesadaran masyarakat tentang pentingnya perilaku hidup sehat dan memberikan motivasi kepada mereka agar mau menerapkan pencegahan penyakit melalui pemanfaatan fasilitas kesehatan yang ada (22).

Sejalan dengan hasil penelitian Kurnianingsih, Dharminto, Sri Winarni (2019) yang menunjukkan bahwa peran kader memiliki hubungan terhadap pemanfaatan posyandu lansia Bandarjo ( $\mathrm{p}=$ 0,004) (31). Hal ini berhubungan disebabkan karena pelayanan yang diberikan kader membuat lansia menjadi tertarik untuk memanfaatkan posyandu lansia. Didukung pula oleh hasil penelitian Setyoadi, Ahsan dan Abidin (2013) yang menjelaskan bahwa peran kader yang baik akan mempengaruhi derajat hidup lansia disebabkan karena kader kerap memberikan dorongan secara positif dengan membimbing dan mengawasi aktifitas dalam sehari-hari serta mengedukasi lansia untuk melaksanakan pemeriksaan secara intensif ke posyandu lansia ataupun puseksemas (32).

Dalam penelitian ini lansia yang merasakan peran kader kurang baik dan tidak memanfaatkan posyandu lansia disebabkan karena belum pernah mendapatkan informasi 
ataupun sosialisasi dari para kader mengenai kegiatan posyandu lansia. Hal ini bertolak belakang dengan teori tentang tugas kader menurut Ismawati, Pebriyanti dan Proverawati (2010) bahwa salah satu tugas kader adalah mengunjungi rumah atau menyuluh secara perorangan sebagai langkah selanjutnya dan upaya untuk mengajak lansia hadir di posyandu lansia (26). Lansia yang merasakan baiknya peran kader namun tidak memanfaatkan posyandu lansia disebabkan karena faktor pekerjaan dan pengetahuan yang kurang akan manfaat posyandu lansia sehingga mereka tidak memanfaatkan posyandu lansia.

Tidak sejalan pula dengan hasil penelitian Sari, Asrinawaty, Dhewi (2020) yaitu bahwa peran kader tidak ada hubungan terhadap pemanfaatan posyandu lansia di wilayah kerja Puskesmas Banjarbaru Selatan (20).

Dari hasil penelitian ini bisa disimpulkan bahwa kurang baiknya peran kader dapat menyebabkan semakin rendahnya pemanfaatan posyandu lansia. Sebaliknya, semakin baik peran kader maka akan semakin baik pula pemanfaatan posyandu lansia.

\section{KESIMPULAN DAN SARAN}

Proporsi lansia yang melakukan pemanfaatan Posyandu Lansia di wilayah kerja Puskesmas Payo Selincah Kota Jambi masih sangat rendah yaitu sebanyak 8 orang (26,5\%). Determinan yang berhubungan secara signifikan dengan pemanfaatan posyandu lansia di wilayah kerja Puskesmas Payo Selincah Kota Jambi adalah jarak dan peran kader. Perlu dilakukan peningkatan upaya sosialisasi dan promosi mengenai posyandu lansia oleh kader kepada masyarakat dengan memanfaatkan media promosi kesehatan. Penambahan jumlah posyandu lansia dan penempatan lokasi posyandu yang terjangkau juga perlu dilakukan mengingat begitu begitu luas dan jauhnya wilayah tempat tinggal masyarakat.

\section{DAFTAR PUSTAKA}

1. Biro Hukum \& Humas BPKP. Peraturan Pemerintah Republik Indonesia Nomor 43 Tahun 2004. Peratur Pemerintah Republik Indones Nomor 43 Tahun 2004. 2004;1-17.

2. BPS. Statistik Penduduk Lanjut Usia. 2018.

3. United Nations. Department of Economic and Social Affairs. World population ageing 2019: Highlights. Vol. 40, United Nations. Department of Economic and Social Affairs. 2019. 401307-40-1307 p.

4. Badan Pusat Statistik. Statistik Indonesia. 2019.

5. Badan Pusat Statistik. Statistik Penduduk Lanjut Usia. In Badan Pusat Statistik; 2019. p. xxvi + 258 halaman.

6. Dinkes Provinsi Jambi. Profil Kesehatan Provinsi Jambi 2018. 2019;63244(38). Available from: https://www.depkes.go.id/resources/do wnload/pusdatin/profil-kesehatanindonesia/profil-kesehatan-indonesia2018.pdf diunduh tanggal 11 Novembe 2019

7. Dinas Kesehatan Kota Jambi. Profil Kesehatan Kota Jambi. Kota Jambi; 2018.

8. Kemenkes RI. Profil Kesehatan Republik Indonesia Tahun 2017. 2018. 107-108 p.

9. Badan Pusat Statistik. Statistik Indonesia [Internet]. Badan Pusat Statistik; 2018. Available from: http://www.ghbook.ir/index.php?name= 


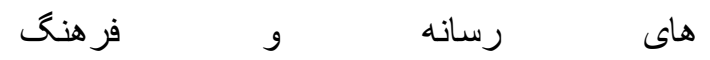
نوين\&option=com_dbook\&task=readonl ine\&book_id=13650\&page $=73 \&$ chkhas $\mathrm{hk}=\mathrm{ED} 9 \mathrm{C} 9491 \mathrm{~B} 4 \&$ Itemid $=218 \&$ lang $=\mathrm{f}$ a\&tmpl=component

10. Kemenkes RI. PUSDATIN. Situasi Lanjut Usia (Lansia) di Indonesia. 2016.

11. Sofiana J, Laelatul Qomar U, Puji Astuti D. Faktor-Faktor Yang Mempengaruhi Kunjungan Lansia Ke Posyandu Di Desa Semali Sempor Kebumen. J Ilm Kesehat Keperawatan. 2018;14(2).

12. Dinas Kesehatan Kota Jambi. Profil Kesehatan Kota Jambi Tahun 2018. 2018.

13. L A. Keperawatan lanjut Usia. I, editor. Yogyakarta: Graha Ilmu; 2011.

14. Notoadmodjo S. Promosi Kesehatan: Teori dan Aplikasi. Jakarta: Rineka Cipta; 2005.

15. Yuniati Faiza DY. Pemanfaatan Posyandu Lanjut Usia. J Kesehat Politek Kesehat Palembang [Internet]. 2014;1:30-3. Available from: https://jurnal.poltekkespalembang.ac.id/ index.php/JPP/article/download/170/13 3

16. Notoadmodjo S. Metodologi Penelitian Kesehatan. Jakarta: Rineka Cipta; 2010.

17. Aryantiningsih DS. Faktor-Faktor yang Berhubungan Dengan Pemanfaatan Posyandu Lansia di Kota Pekan Baru. anNada. 2014;1(2):42-7.

18. Notoadmodjo S. Promosi Kesehatan \& Ilmu Perilaku. Edisi Pert. Jakarta: Rineka Cipta; 2007. 133 p.

19. Intarti WD, Khoiriah SN. Faktor-Faktor yang Mempengaruhi Pemanfaatan Posyandu Lansia. J Heal Stud. 2018;2(1):110-22.

20. Sari GI, Asrinawaty, Dhewi S. Faktor faktor yang berhubungan dengan pemanfaatan kegiatan posyandu lansia di wilayah kerja puskesmas banjarbaru selatan tahun 2020. 2020;

21. Purnama S, Sudirman, Yusuf H. Faktor
Yang Berhubungan Dengan Pemanfaatan Posyandu Lansia Desa Tikopo Kecamatan Bokat Kabupaten Buol. Вестник Росздравнадзора. 2017;6(October):5-9.

22. Rusmin M, Bujawati E, Habiba N. Faktor - Faktor Yang Berhubungan Dengan Di Wilayah Kerja Puskesmas Somba Opu Kabupaten Gowa Tahun 2015. Al-Sihah Public Heal J. 2017;9(1):9-18.

23. Rahayu ND. Faktor-Faktor Yang Berhubungan Dengan Pemanfaatan Posyandu Lansia (Studi Kasus di Wilayah Kerja Puskesmas Srondol). 2019; Available from: https://lib.unnes.ac.id/35677/

24. Sayati D. Faktor-faktor yang berhubugan dengan pemanfaatan posyandu lansia di puskesmas 7 Ulu Pelembang Tahun 2017. J 'Aisyiyah Med [Internet]. 2018;1(2):166-77. Available from: http://jurnal.stikes-aisyiyahpalembang.ac.id/index.php/JAM/article/ download/20/16

25. Darmawan AAKN. Perilaku Kunjungan Masyarakat terhadap Pemanfaatan Pelayanan Posyandu. J Dunia Kesehat [Internet]. 2016;5(2):29-39. Available from:

https://www.neliti.com/publications/764 42/faktor-faktor-yang-mempengaruhiperilaku-kunjungan-masyarakatterhadap-pemanfaat

26. Ismawati $\mathrm{C}$, Pebriyanti S, Proverawati A. Posyandu \& Desa Siaga. Cetakan I. Yogyakarta: Nuha Medika; 2010. 45-57 p.

27. Sunaryo, Wijayanti R, Kuhu MM, Sumedi T, Widayanti ED, Sukrillah UA, et al. Asuhan Keperawatan Gerontik. Christian P, editor. Yogyakarta: Penerbit Andi; 2016.

28. Maulia B, Kurniawati I. Hubungan Antara Pengetahuan, Dukungan Keluarga dan Jarak dengan Kunjungan 
Lansai ke Posyandu Lansia Anggur Handil, Terusan Kecamatan Anggana Kabupaten Kutai Kartanegara. 2018.

29. Uji Utami KA. Pengaruh Kader Terhadap Pemanfaatan Posyandu Lansia di Deesa Kragilan. 2019;III(2):315-21. Available from: http://repositorio.unan.edu.ni/2986/1/56 24.pdf

30. Zakir M. Faktor-Faktor Yang Berhubungan Dengan Pemanfaatan Posyandu Lansia Kencana. J Keperawatan. 2014;X(2):64-9.

31. Kurnianingsih, Dharminto, Sri Winarni AM. Faktor-Faktor Yang Berhubungan Dengan Tingkat Pemanfaatan Posyandu Lansia Di Kelurahan Bandarjo Kecamatan Ungaran Barat, Kabupaten Semarang Tahun 2019. J Kesehat Masy. 2019;7(4):573-80.

32. Setyoadi S, Ahsan A, Abidin A. Hubungan Peran Kader Kesehatan Dengan Tingkat Kualitas Hidup Lanjut Usia. J Ilmu Keperawatan. 2013;1(2):pp.183-192. 